УДК 811.163.4.09 Караџић, Вук Стефановић https://doi.org/10.18485/msc50_vuk_trsic.2021.ch3

\title{
Benjamin Stolz
}

\section{THE ORIGINAL AND TRADITIONAL IN VUK'S LANGUAGE}

In the twenty-three years since the last great fête for Vuk Stefanović Karadžić, a large number of important studies have been produced which have helped clarify Vuk's role in the history of modern Serbo-Croatian. The last two decades have also yielded thorough thorough analyses of the linguistic situation preceding Vuk among both the Serbs and Croats; and equally illuminating research has traced the development of the standard language (in both variants) since Vuk's passing. We are therefore in a much better position to appreciate Vuk's achievements on the bicentennial of his birth than we were in 1964, on the centennial of his death. Putting aside a detailed examination of the complex and multifaced problems connected with the rise of modern Croatian, let us focus primarily on Vuk's impact upon the evolution of Serbian. In doing so we propose to ask the following questions: 1 ) To what extend was Vuk's language a break with preceding traditions? 2) To what extend did Vuk's language preserve links with previous traditions? 3) In what ways can Vuk's reform be viewed as a model of language planning?

\section{Vuk's language as a break with tradition}

It has become a common place to contrast the development of modern Russian, which represents a uniquely successful marriage of native East Slavic and Church Slavonic elements, with that of other modern Slavic literary languages. In the case of Serbo-Croatian the formulation of the great Russian lingust N. S. Trubeckoj is typical. After describing the decay of early native writing traditions and the short-lived slavenosrpski interlude of the eighteenth century. Trubeckoj (1927: 70) provides a succinct comparison:

Современный сербохорватский литературный язык возник ex abrupto на основе простонародного говора. Создателем этого языка был смелый реформатор Вук Караджич. Таким образом, в противоположеностъ истории образования русского литератур- 
ного языка, характеризуемой постепенностыю и огранической непрерывностию литературно языковой преемственности, история сербохорватского литературного языка отмечена резким и полным разрывом с традицией и, при том, разрывом не вынужденным, а добровольным.

There can be no dobut that Vuk's „new” language as presented in his early works was a sharp break with the existing writing tradition of the leading Serbian intellectuals - the „Hunguarian” Serbs of the Vojvodina. Vuk, however, was by no means the first Serbian writer to employ the spoken language in writing - indeed, it had already come into wide use - or to recommend the vernacular as a basic for the literary language. The cosmopolitan od erudite Dositej Obradović, for example, had attempted to write in the Serbian vernacular, recognizing the fact that all the major European literary languages of the day were fundamentally vernacular in their structure, and that increasing emphasis upon the vernacular component in the modern languages was crucial for the education of the common people (1961: 64-65). Vuk's revolutionary solution took the democratizanting process a step further. With Vuk Karadžić (spurred on by his mentor Kopitar) it was not a matter of adjusting the conteporary literary language in the direction of the vernacular in order to make it comprehensible to the common people, but of enshrining the language of the peasant as the basic for his standard. This was indeed an extreme solution, for it pitted the spoken language of Vuk's illiterate Western Serbia (East Hercegovina dialect) against the remnants, many of whom were well schooled in the classics. And, more generally speaking, Vuk pitted his supposedly untainted rural language, ridiculed as a backwoods patois by its detractors, against the supposedly corrupt speech of the towns. Publishing a grammar and dictionary of this new literary language together with folk songs which he offered as exelted specimens of the oral traditional poetry of his unlettered kinsmen, and polemicizing ruthlessly in support of this language, Vuk set fimself up as an expert on the genuine Serbian language and effectively cut the ground from under his better - educated opponents in Vojvodina. Vuk's uncompromisingly populist language reform was thus strikingly anti-establishemnt, so much so that many of his critics viewed it as anti-Orthodox (therefore anti-Russian) and pro-Catholic (thus pro-Austiran). The offensive vocabulary („šmuciditet") of Vuk's 1818 Rječnik was epunged from later editions and forgotten, but his reducial changes in the alphabet and orthography were not officially accepted until 1868, four years after his death. Vuk's language evolved during his lifetime, absorbing features that were regularizing, urbanizing and archaizing, and that broadened its dialect base (Ivić 1966: 66-69). These changes made 
Vuk's norm acceptable to a wider range of SerboCroatian speakers and significantly improved its viability as a standard language, but it retained one important trait that was never welcomed in Serbia - the jekavian reflex of jat. This reflex, part of Vuk's native Tršić speech, which from larger perspective represented the East Hercegovina dialect, functioned as an important link with the earlier vernacular literature of Dubrovnik; this helped make Vuk's language ultimately acceptable to the Croats, but has persisted to this day as one of the most visible emblems of the schism between the Eastern (Belgrade) and Weastern (Zagreb) variants of Serbo-Croatian.

\section{Vuk's lanugage as a link with previous traditions}

Cereful analysis of Vuk's complete opus, inculding his personal correspondence, has shown that Vuk was never able to free himself completelz from previous writing traditions, and that he came over time to recognize that no standard language besed exclusively on the speech of unlettered peasants could function as a medium for a civilized European nation (Ivić 1966: 68-69) What was important for Vuk, however, especially in the critical initial phase of his career, was his link with previous traditions that were strongly in nature. These were both oral and written; paradoxically, the first was literary and the second, non-literary. We are speaking here of course, of oral traditional literature (verbal folklore) and of the vernacular scribal tradition of administrative and business correspondence (Stolz 1973: 326). Linguists have frequently singled out both as potential sources for modern standard languages, and no less a philologist than Vatroslav Jagić found room to discuss both elements in his Historija književnosti naroda hrvatskoga i srpskoga (1867: 104-117, 127-145, 173-174, 202-204).

Vuk's learned Slovene mentor Jernej Kopitar can be credited with awakening his professional interest in Serbo-Croatian folklore as well as in the reform of the Serbian literary language. A fundamental tenet of Kopitear's Herderian philosophy was that a vernacular-based literary language could be found in its natural state in the oral traditional poetry of the peasant. His earlier pronouncements on this subject, as well as his efforts to encorage the collection of such material are well documented (Kopitar 1982: 200-201). Not surprising, then, is the fact that Vuk's first publication after meeting Kopitar was a volume of Serbian folk songs, Mala prostonarodnja sloveno-serbska pjesnicarica (Vienna, 1814; reprinted 1965). It is scarcely possible to deny that this little book, the first of Vuk's voluminous published collection of folklore, played a role in his success as a language reformer. The question is, what was the pre- 
cise nature of that role? One idea with a certain intellectual currencly seems to combine elements of the Herderian thesis mentioned above with recent trends in classsical studies and the theories of modern dialectology, and asserts that Vuk based his new Serbian literary language on a neoštokavian folklore koine. Aleksandar Belić, apparently the first to use the term „koine” in this context, applied it specifically to the post-migrational neoštokavian dialekt base (i. e. the greatly expeanded area resulting from the metanastazička kretanja) underlying Vuk's language; while he repeatelly stressed the role of verbal folklore in Vuk's reform, he wavered somewhat, finally reducing its connection with Vuk's language to one of "developmental reciprocity” (1951: 185; 1968; 6-8). Gerhard Gesemann had earlier called the language of the folk songs in the Erlangen manuscript (first half of the eighteenth century) a štokavian-based literary supradialect (1925, pp. XXIII-XXIV)). More recently Dalibor Brozović, N. I. Tolstoj, and the Iate V. V. Vinogradov have all subscribed to the folklore koine concept; others have found the idea appealing but in need of further documentation (Stolz 1973: 325-328; Havranek 1965: 262). There are at least two types of evidence that suggest that it is an exaggeration to equate Vuk's language even in its inital shape with a folklore koine. First, folklorists have shown that Vuk, far from recording material in the manner of a modern field worker, was a careful adapter and editor of folklore texts, whethever he collected them personallz or not (Stolz 1973: 325). Apparently Vuk even converted some ekavian junačke pesme from Srem into „Hercegovinian” jekavian - a practice he ceased when Jakob Grimm asked some probing questions (Matić 1964: 28-30). Second, there is the evidence of earlier collections. When we examine the Cyrillic Erlangen manuscript of Serbo-Croatian folk songs, for example, we in fact find little to suggest a neoštokavian koine base: rather, the largely štokavian manuscript presents the linguistic mosaic one might expect in the Vojna granica, where soldiers of diverse dialects were thrown together (Stolz 1973: 326; Matešić 1959: 2, 186-187). Even earlier texts fail to reveal a koine: the language of the famous bugarštice in Hektorovićs Ribanje (a čakaivan piscatorial eclogue published in 1568) clearly indicates their štokavian provenance, but not surprisingly these longline folk songs display a mixture of dialect traits, both štokavian (ekavian and jekavian) as well as čakavian (Mladenović 1968: 188-189). Proving the existence of a folklore koine will require a good deal more evidence that has been gathered up to now in support of such a theory. Materials copied in uncontrolled and frequently unknown circumstances a century or more ago leave us grasping at straws; an analysis of electronic recordings (on cylinder, disc, wire, and tape) made during the twentieth century, however, might enable us to compare the language of the singer and his song with the speech of his dialect. 
Perhaps the entire question of a putative folklore koine is beside the point. Whether or not we attribute the success of Vuk's language reform to a folklore koine or to a neoštokavian cultural interdialect or merely to the relative uniformity of the expanded post-migrational neoštokavian area, Vuk's published collections of folklore served important functions. First, they provided normative models, albeit highly specialized and somewhat archaic, of the vernacular of semi-literate Turkish Serbia. Second, the junacke pesme especially supplied powerful mythic bonds with Serbia's past glory and helped fuel the nation's resurgence. Third, and perhaps most important, the published collections of heroic epic, by gaining European recognition, offered the dignitas and prestige needed to attract the next generation to Vuk's vernacular-based literary language.

It was not Vuk's intimate knowledge of Serbian folklore, however, that first brought him to the attention of Jernej Kopitar, but an opet letter from Vuk to Karađorđe (unpreserved) (Stojanović 1924: 15) about the collapse of rebel Serbia. An examination of Vuk's early prose provides a fairly good picture of what this modest work might have looked like. Even though it probably was generously sprinkled with slavenosrpski forms, the manuscript must have been sufficiently vernacular in its basic structure to pique Kopitar's curiosity about its author. What sort of earlier schooling and experience shaped Vuk's writing up to this point? The details of Vuk's skimpy formal education are well known and need not be rehearsed here. Suffice it to say that Vuk, although mostly selftaught, was clearly precocious and had gained a reputation for book-learning in the illiterate environment of Jadar (Western Serbia). Vuk was a member of a very thin layer of literate young men in Turkish Serbia and his early experience as a scribe in this largely oral culture gave him all the credentials necessary for service as a scribe and civil servant in Karađorđe's rebel government. This was the career he abandoned when he fled Serbia in 1813 to escape the invading Turks.

Vuk was a product of his environment: an extraordinarily gifted autodidact whom Kopitar called a grammatical genius and who as a scribe in Karađorđe's Pravitelstvujušči Sovjet (Governing Council) was known as an expert on the Serbian language. But which Seriban language? Vuk's schooling had given him a knowledge of Russian Church Slavonic plus a smattering of Latin, and German, and despite his best efforts, his writings frequently bore traces of the slavenosrpski tradition of the Vojvodina. Vuk's real forte was the vernacular language of his native oral culture, a language deeply embedded in his linguistic consciousness from a very early age. Vuk had a highly developed linguistic duality, one could almost say diglossia within himself: a complete 
mastery of the Serbian vernacular in its most cultivated oral form, and a decent grounding in the slavenosrpski writing tradition to which he had been exposed. But his service as a scribe, as I have tried to show elsewhere (Stolz 1973: 328), gave Vuk the practical experience necessary to understand how the oral vernacular could be used in a plain written style, and how one might actually forge a modern standard language from it.

Advanced linguistic competence is not restricted to literare societies. The pioneering American descriptivist Leonard Bloomfield in a study of completely non-literate American Indians succeeded in showing that certain individuals - male and female - within such groups are recognized as arbiters of correct speech, repositories of knowledge about traditional speech styles and their appropriate function, in other words, models of cultivated language use in an unlettered society (Bloomfield 1964: 394-396). Vuk lived in both worlds, the oral and the literate -or chirographic, as Walter Ong (1982: 2) has called it - and was able to transfer his high competence from one mode to the other. Vuk admitted that many Serbs before him had written in the vernacular to the best of their abilities; and, like Kopitar, Vuk recognized Dositej Obradovićs merits in this cause - though he clearly saw that Dositej had failed to carry his own program to its logical conclusion. Vuk was fascinated by the whole phenomenon of orality - the oral mastery of language not just in folklore but also in more practical spheres. He noted with admiration the ability of the illiterate Petar Teodorović Dobrinjac, whom he had witnessed dictating administrative letters to important personages: „Читати није знао, али је био једини старјешина у Србији овога реда, који је писарима знатнија писма (на велику господу) казивао ријеч по ријеч (т. ј. диктирао)" (Karadžić 1969: 99-101). Vuk had early seen the distinct advantages of a vernacular-based written language for administrative and military communication; he pointed out how comical virtually useless was slavenosrpski in the hands of inept scribes: Russian officials in Wallachia, he recalled, had requested in 1810 that future Serbian dispatches be written in the Serbian vernacular, for which they had interpreters. Slavenosrpski gibberisch was completely beyond them (Karadžić 1894: 166, 176-181; Stojanović 1924: 157).

A wonderful example of the vernacular prose of rebel Serbia is Prota Matija Nenadovićs Memoari, first edited and published by his son Ljubomir P. Nenadović, reprinted many times and only partially preserved in manuscript (Radević 1972). Prota Matija, president of the Governing Council (where Vuk served as a scribe), was actively engaged in several important capacities during the first Uprising. His memoirs are written in a rough-and-ready, strongly vernacular language with a few slavenosrpski forms and Church Slavonicisms, but even more Turkisms (Jerković 1977; Jović 1978). Prota Matija kept his 
memoirs secret throughout his life and once said that he didn't know how to write for „trukovanje”. Vuk allegedly responded, „Напишите ви, тако, као што причате, а ако почнете учено писати, ништа неће ваљати" (Popović 1968: 160). Prota Matija tells us in his memoirs of his first experience during the Uprising of writing to important people at the request of a lieutenant in the Austrian Freicorps "of the Roman faith, but full of goodwill and fairness”. The lieutenant asks if the Prota knows how to write, and he responds thus: „Али ту валяду политичне титуле кое я незнамъ нити умем како валя написати, обраштер лайтнеръ.” The lieutenant: „Прођи се ти, човече, титула и политика веће онако као што си мене казивао напиши, и дай я ћу и послати.” (Margin: „Прођи се ти човече политика, што е тужба простіа то е вЂроватніа; ако ти нима политично пишеш они ће теби политично одговорити пак нећеш знати где си”)... „А он рече, 'иди оче Якове, донеси му што треба за писанъ'. Поп Яков отрча на кочіа и донесе ми давит, артіе 4 табака и перо. Я пређем у Забръжъ, у кућу Пантеліе Ружичића и на столици малой клечећи пишем а Пантеліа држи свећу ноћом и како сам умъо писо Митрополиту Стратимировићу а друго сад не знам управо, заборавіо сам или сам принц Карлу или ђенерал команди, ербо мі е обое поминьо лайтнер. Колико сам мого описати зулум кои смо трпили од яньичара, и да би іош трпили..." (Prota Matija Nenadović's ms: 71-72; cf. Prota Matija Nenadović 1969, pp. 110-112.)

And later, in describing an exchange of communiques, the Prota amustinly quotes knez Teodosije regarding Karađrođe's illiteracy: „вели кнез

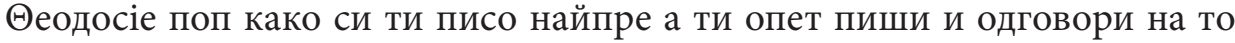
писмо, а црни Ђорђе не зна писати а нема ни писара он само зна турке тући..." (ms: 77)

Immersed as he was in the oral world of his birht, Vuk was, then, one of a tiny elite of literate young men from Turkish Serbia, where even the first two rebel princes, Karađorđe and Miloš, were unable to read or write. Much of Vuk's revolutionary language reform was connected with the practical goal of raising Serbia to a European standard of literacy, and he correctly perceived that the quickest way to achieve this was with a vernacular-based language and a "phonetic” (really phonemic) writing system. In his charming little primer published in Vienna in 1827 Vuk (1827: 1) underscores the venerable age of literacy and the fact that the Serbs had received in with Christianity, a thousand years earlier, but he could not resist noting the paradox that letter-writing was a common motif of verbal folklore: „и прем да се у нашим народним пјесмама врло често књиге пишу и уче, опет су у народу нашему још врло ријетки људи, који знаду читати и писати!" 


\section{Vuk's reform as a model of language planning}

If Trubeckoj was not entirely right when he said that the history of Serbo-Croatian is characterized by a sharp and complete break with tradition, he was indeed tight in calling the break „not forced, but voluntary”. Vuk's reform enjoyed no governmental support either in Vojvodina or in Serbia itself, and was anathematized by the powerful Orthodox Church hierarchy. Thus, Vuk's fifty-year campaign scarcely fits the present-day type of government-sponsored planning which has been defined as „a deliberate and systematic attempt to affect the course of societal language acquisition and use”, or where "language planning is often but one facet of a comprehensive and swift-moving program of social engineering" (Smith et al 1977: 285). On the other hand, Vuk's revolutionary program stands out as a classic example of language planning defined as ,the exercise of judgement in the form of choices among available linguistic forms" or more concisely "the evaluation of linguistic change" leading to the preparation of „a normative orthography, grammar, and dictionary for the guidance of writers and speakers in a non-homogeneous speech community" (Haugen 1972: 161-162). Because Vuk lacked government sponsorship for his reform and in the fact had powerfully entrenched religious and political forces arrayed against him, he did not enjoy the advantage of having his vernacular-based standard language and orthography introduced in the schools during his lifetime.

Vuk's language reform began as a revolution from outside, a „diaspora revolution". Like any revolution, it required first of all that conditions be ripe for its success, and it also required a sound philosophical-ideological basis, a leader of extraordinary charisma, tenacity, and willpower, and gifted followers who could carry on the fight to its ultimate victory. Vuk provided the leadership, waging a brilliant campaign both strategically and tactically over a period of fifty years. But it is doubtful that his reform would ever have taken place, that he could have implemented his language plan, without the direct guidance - at least initially - of Jernej Kopitar, his scholarly Slovane mentor; and without the assistance of his learned Serbian protege Đura Daničić it is unlikely that Vuk's reform would have been accepted - first in Serbia and then in Croatia.

The neoštokavian vernacular which formed the basis for Vuk's „new” literary (standard) language was, as I have said earlier, already in use as a written language and had been used as such in various parts of the Serbo-Croatian speech area for centuries. Thus, at the beginning of the nineteenth century neoštokavian vernacular was certainly in a more advanced condition that the one which Einar Haugen has defined as „undeveloped” (Haugen 1972: 244): 
a language "that has not been employed in all the functions that a language can perform in a society larger than that of the local tribe of peasant village." Rather, it was underdeveloped. In order to become a fully developed standard language, the neoštokavian vernacular had to codified and elaborated; and most important it had to be accepted by the speech community. Vuk's selection of his native East Hercegovina dialect as the basis for the new standard language - which seemed a quaint aberration to the educated Serbian elite of Vojvodina - was in reality a stroke of genius in language planning. By selecting this central neoštokavian dialect Vuk achieved two things: 1) he forged a link with the Dubrovnik literary traditions of the Renaissance and Baroque, which ultimately helped make his reform attractive to the Croats; and 2) he placed himself in a position of superiority vis à vis the Vojvodina élite, for he was quickly able to establish himself as an expert in an area where his opponents were mere dilettantes - the folk language.

In order to achieve acceptance the proposed new standard language had to garner prestige. Vuk was able to accomplish this through a life-long campaign of research and publication in fields as varied as folklore, ethnography, applied and historical linguistics, lexicography, history, and philology - not to mention the enormous network of contacts he maintained with his voluminous correspondence. All of this brought him scholarly recognition throughout Europe.

Though he traveled much and was tempted to move from time to time, Vuk had the good sense to retain his base in Vienna. As a world capital, one of the great European cities, and the nerve center of the Danubian Empire, Vienna afforded Vuk a location unmatched in its strategic value. There he was able to receive important visitors from all sides: not just his fellow Serbs and Croats, but Slavs from elsewhere in the polyglot Habsburg Empire, and from Russia, too. Moreover, through Kopitar he gained access to some of the leading German scholars and poets of that era. Thus, while Vuk's proposed new standard language was rural, populist, and West-Serbian in its basic shape, it managed to achieve approbation at the very highest levels of European scholarship, enabling Vuk to set up the neoštokavian-speaking peasant as a „counter-elite” to the educated Serbian elite of Hungary. By remaining in Vienna, Vuk avoided the dangers inherent in being a prophet in his own country while at the same time winning European prestige for himself and his language reform. Vuk had the semiotic instinct to mark his origin in Turkish Serbia: with his fez, his handleber moustache and his wooden leg he became the best-known Serbian intellectual and cultural figure of his day.

By the mid-1840's, when Vuk's fame was already widespread outside Serbia and when he was in the midst of his protracted polemic with his learned 
adversary Jovan Hadžić (Miloš Svetić), two articles appeared which reveal the level of prestige attained by Vuk among the Serbian elite of Hungary. One was a translation from German published in the „Bačka vila”, vol. III (Novi Sad) 1844, edited by Petar Jovanović (1844: 95-114), who was known as the „bačvanski Ilir." The language (though not the orthography) of the translation is nearly Vukovian, with occasional Church Slavonicisms and Russisms, but naturally enough it fails to incorporate the $x$ which Vuk had introduced by this time, or the jekavian reflex of $\check{e}$. Notable here is the inclusion of some decasyllabic Serbian junacke pesme, which are favorably compared with Homeric epic. The author (1844: 104-114) points out that this Serbian folk poetry became known abroad only at the beginning of the nineteent century and that Vuk Stefanović Karadžić was the first among the Serbs to collect and publish such material.

If Jovanovićs translation, with its favorable mention of Vuk's activities (appearing as it did in Miloš Svetićs bastion) was symptomatic of Vuk's growing favor in Vojvodina, an article by Jovan Subotić, editor of "Serbskij letopis” (vol. 75,1846 ) was a veritable stamp of approval by an organ of the Matica srpska. Vuk himself was stunned by Subotićs piece, and expressed his delight and surprise in a letter to the Russian historian V. I. Grigorovič (Vinogradov et al 1965: 189). Nor could Đura Daničić in his Rat za srpski jezik i pravopis (Buda 1847) - the coup de grace in Vuk's fight with Miloš Svetić - fail to quote from Subotićs article, adding „Јован је Суботић цијелијем онијем чланком освјетлао образ свему народу нашему” (Daničić 1976: 63). No wonder Vuk and Daničić were pleased. Subotićs article calls Vuk a successor to Dositej Obradović and praises nearly all aspects of Vuk's wok, including his orthography. Serbian folk songs, writes Subotić (1846: 104-124), are not mere Volkslieder but Nationalieder, and stand closer to the poetry of the ancient Greeks than does the poetry of any educated European nation. When Europe recognized not only the inherent value of the Serbian folk poetry but also its language, learned Serbs, writes Subotić, could no longer claim that books could not be written in the vernacular. Describing Vuk's thirty years as a folklorist and language reformer, Subotić (1846: 121-123) writes:

Ту є онъ првый самымъ чистымъ народнымъ єзыкомъ писати почео, и єднако писао; онъ $є$ науки и напредованю єзыка србскогъ своимъ неуморнымъ скуплянъмъ матеріяла, врло много помогао. Доситеј є увео народный єзыкъ у кньиге, Вукъ намъ $є$ показао, кои $€$ то народный єзыкъ; Доситей намъ $є$ показао, да треба народнымъ єзыком ъ кньиге писати, Вукъ пакъ показао намъ є, како треба да пишемо... 
Изъ почетка є Вукъ у єзыку претеривао, и подъ народный єзыкъ, све што є пучко, узимао: но ово є съ єдне стране наравно было, єръ коя реформа у почетку ніє на противну страну преко границе прешла, съ друге стране пакъ было є и нуждно, єръ ако се хтъло добыти нъшто, морало се искати све. Служило є пакъ то на добро іоштъ и у томъ, што се тымъ таки ясно дознало, шта нетреба, дакле и шта треба. И онъ самъ већъ $є$ оддавно на уже шестаръ свой повукао, съ друге пикъ стране земльиште народногъ єзыка разширіо. Садъ му ніє Ерцеговина србскій Паризъ, него му с Ерцеговина свуда, кудъ се србски говори, т. є. све земль, у коима Србльи живе и србски говоре, єднако му се вредне чине, да се на ньи вниманіє обрати. Крозъ Вуково дъланъ постало є србско Кньижество и другомъ славенскомъ свъту живећимъ. У смотренію єзыка имао є Вукъ найвећій упливъ на србске списателъ, коє directe, коє indirecte, т. є. коє, што су по нъму ишли, коє противъ нъга.

The year 1847 is often called a milestone in Vuk' campaign to install his vernacular-based standard language among Serbs. Four major works were published that year which supposedly validate that claim: Njegošs Gorski vijenac; Radičevićs Pjesme; Vuk's translation of the New Teastament; and Daničićs Rat za srpski jezik i pravopis. But was the language of each of these works sufficiently uniform or close enough to Vuk's earlier normative works to be called Vukovian? The answer is no. Without discussing the issue here, however, it can be said that their publication, like the favorable reaction toward Vuk's campaign reflected in the journals mentioned above, is evidence that by the late 1840's Serbs were ready to embrace a vernacular-based standard language which, if not identical to Vuk's in orthography or phonology or even lexicon, was far closer to the Vukovian norm than to the slavenosrpski tradition of fithy years earlier. What led to the ultimate success of Vuk's hard-fought reform among the Serbs? The historical preconditions were two in number: 1) the resurgence of Belgrade as the administrative center of the semi-autonomous pašaluk and later of the autonomous Principality of Serbia in 1833; the restoration of Belgrade as a "national capital” caused a shift of Serbian cultural power southward from Budapest and Novi Sad;2) and the coming of age of a generation of Serbian youth who had attended Europan universities, where they were introduced not only to Romanticism and democratic ideas, but also to the prestigne and legitimacy of Vuk's language - which Vuk had won through his published works (in the original and in translation) - and to the recognition accorded Serbs, for example, in von Ranke's Die serbische Revolution (for which Vuk had provided first-hand information). Two examples of 
that first generation of Europan-educated urban intellectuals centered in Belgrade are Ljubomir Nenadović (1826-1895) and Đura Daničić (1825-1822).

The first was a writer and the second a linguist, philologist, and language reformer. If it is true that language planning can be intelligently performed only by linguists, it is also true that the acceptance of a reform by the general public depends upon its adoption by writers of all kinds, including journalists. Ljubomir Nenadović, prolific and popular in his day, was one of the first and one of the most influential in propagating Vuk's reform in Serbia. Nenadović, son of Prota Matija (whose memoirs he edited) studied for five years at the gymnasium and lycee in Belgrade before becoming a wandering scholar in 1844. After a year at Prague Nenadović attended the universities of Berlin, Heidelberg, and Paris. Though he never took a final examination and returned to Belgrade from revolutionary Paris in 1848 without a diploma, he seems to have enjoyed his studies, reading Czech and Serbian folk poetry (Vuk's collection), Radičević, the Dubrovnik poets, philosophy, religious history and Slavic philology. In 1850 he founded the popular journal „Šumadinka”. While not considered a major writer, Nenadović is best remembered for his mastery of the vernacular language and his effortless, unselfconscious prose, which according to one critic marks the advent of the urban era in the development of the vernacular-based Serbian literary language (Popović 1972: 269). And he was a personal friend of Đura Daničić. In a letter to Daničić (who was in Vienna) of December 1, 1848 Nenadović complains of the political situation in Belgrade, reporting that Branko Radičević has been forced to leave by the police through the machinations of a certain „два, три просвјештена брата из аустрије”; and that although „наше предложење за слободу ортографије неће се одобрити" Nenadović proclaims,

„- Ја овом ортографијом пишем како у приватним тако у службеним пословима, и кад су ме питали, што пишем вако, ја сам им одговоријо, да с' тога пишем што је забрањена, јер то ми је прво доказателство да је боља -"

Significantly, Nenadović closes with „Поздрави Г-на Вука и све друге и пиши нам." (Šević 1925: 234-237). The persistance of Church Slavonicisms such as predloženje and dokazatelstvo is typical of Serbian at this transitional stage in its history - even in the usage of Vuk's supporters.

Daničićs career and accomplishments are too well known to need a detailed rahearsal here. Born Đorđe Popović in Novi Sad in 1825 (and like Nenadović, the son of an Orthodox priest), he enrolled at the law faculty in Vienna in 1845 but, joining Vuk's circle, took up Slavic linguistics with Miklošić. His Rat za srpski jezik i pravopis was followed by collaboration on the second 
edition of Vuk's dictionary. Then, during a decade and a half in Belgrade he published a number of solid works in grammar, accentology, historical linguistics, philology, lexicography, and a translation of the Old Testament. All of this was of enormous importance in the affirmation of the Vukovian norm in Serbia.

Perhaps Daničićs greatest achievement, however, resulted from his invitation to move to Zagreb as a member (and later secretary) of the newly established Yugoslav Academy (Jugoslovenska akademija znanosti i umjetnosti). With the support and encouragement of Franjo Rački, president of the Academy, and Bishop Juraj Strossmayer, both of whom were strongly „Yugoslav” in orientation, he planned the monumental Rječnik hrvatskoga ili srpskoga jezika, managing to edit and publish only the first volume before his untimely death in 1882 .

It is difficult do overemphasize Daničićs contribution to the victory of Vuk's reform. Thanks to Daničić, there is in fact a modern Serbo-Croatian (Croato-Serbian) standard language, albeit with striking regional variantions. Daničićs work in Zagreb set the stage for the ultimate triumph toward the turn of the century of the Vukovian standard in Croatia - a triumph slow in coming but made possible by the Croatian „Vukovci”, foremost among them Tomo Maretić. Daničićs central role in introducing the Vukovian norm and a phonemic orthography among the Croats is an accepted fact even among linguists who decry certain results of this outside intervention (Jonke 1976: 89, 95; 1981: 50, 53; Katičić 1974: 246; Vince 1978: 593, 601-602). The continued flourishing, a century later, of a Croatian literary language featuring numerous elements of the Illyrian and Post-Illyrian Zagreb School should not surprise us, and in a federative multinational state this is no doubt a healthy sign. Whether such a literary language can become more than a regional variant under conditions of mass communication and education and in the face of competition with a widely-used standard is a question that will be answered by those who speak, read, and write Serbo-Croatian (Croato-Serbian).

As we know, Vuk's reform was not accepted in toto by either the Serbs or Croats. It may not have been perfect, but given the circumstances under which it was codified and the environment in which it was implemented, the resulting standard as it has evolved remains a remarkable achievement. And, given the complexity of the standard language situation in contemporary Yugoslavia owing to historical, cultural, religious and geopolitical factors, one can only imagine how much more linguistically fragmented Yugoslavia might have been without Vuk. 


\section{REFERENCES}

Belić, Aleksandar. 1951. Oko našeg književnog jezika. Belgrade. Srpska književna zadruga. 1968. Savremeni srpskohrvatski književni jezik. Prvi deo: glasovi i akcenat. Belgrade. Naučna knjiga.

Bloomfield, Leonard. 1964 (1972). Literate and illiterate speech. Language in culture and society. A reader in linguistics and anthropology. Ed. Dell Hymes. New York. Harper and Row. 391-396.

Daničić, Đura. 1847. Srpska književna zadruga. 1976. 5-67.

Gesemann, Gerhard. 1925. Erlangenski rukopis starih srpskohrvatskih narodnih pesama. Sremski Karlovci, pp. XXIII-XXIV.

Haugen, Einar. 1972. Linguistics and language planning. The ecology of language. Stanford University Press. 159-186.

Ivić, Pavle. 1966. Tendencija u konačnoj fazi Vukove jezičke reforme. Vukov zbornik. Posebna izdanja SANU, 400. Belgrade.

Jagić, Vatroslav. 1867. Historija književnosti naroda hrvatskoga i srpskoga. Knjiga prva. Staro doba. Zagreb. Albrecht.

Jerković Jovan. 1977. O rukopisu i izdanju Memoara Prote Matije Nenadovića. Zbornik Matice srpske za književnost i jezik. Knjiga 25, sveska 3. 451-460. 1981. Jezik Ljubomira Nenadovića. Novi Sad. Matica srpska.

Jonke, Ljudevit. 1976. Đuro Daničić - prvi urednik Rječnika (od 1867 do 1882). Rječnik hrvatskoga ili srpskoga jezika. Sveska 97. 3. dvadeset i trećega dijela. Dodatak - materijali o Rječniku. Zagreb. 83-95. 1981. Daničićev prilog normi i kodifikaciji hrvatskoga književnog jezika. Zbornik o Đuri Daničiću. Belgrade - Zagreb. Srpska akademija nauka i umetnosti and Jugoslavenska akademija znanosti i umjetnosti. 44-54.

Jovanović, Petar. 1844. Narodna pojezija Srbalja s „kritičnym” pogledom na istoriju. Bačka vila. III. 95-114.

Jović, Dušan. 1978. Osnove književnog jezika Prote Matije Nenadovića. Naš jezik. XXIII, 5. 169-174.

Karadžić, Vuk Stefanović. 1827. Prvi srpski bukvar. Vienna. Reprint Belgrade. 1978. (= Karadžić 1894: 280-291) 1894. Skupljeni gramatički i polemički spisi Vuka Stef. Karadžića. Knjiga prva. Belgrade. Štamparija Kraljevine Srbije. 1969. Istorijski spisi II. Sabrana dela Vuka Karadžića, ed. Radovan Samardžić. Belgrade. Prosveta.

Katičić, Radoslav. 1974. Nešto napomena o postanku složenoga savremenog jezičkog standarda hrvatskoga ili srpskoga. Zbornik Zagrebačke slavističke škole. II. Knjiga 2. Zagreb. Međunarodni slavistički centar SR Hrvatske. 
Kopitar, Jernej. 1810. Patriotische Phantasien eines Slaven.Vaterländische Blätter für den österreichischen Kaiserstaat. Third year. No. IX (5 June 1810). 87-93. 1982. Three editions of Jernej Kopitar's „Patriotische Phantasien eines Slaven," introduction and annotation by Rado L. Lencek, translation by Miriam I. Levy. To Honor Jernej Kopitar 1780-1980. Papers in Slavic Philology 2. Ann Arbor. 188-234.

Matešić, Josip. 1959. Die Erlanger serbokroatische Liederhandschrift: Sprachliche Untersuchung. Munich.

Matić, Svetozar. 1964. Naš narodni ep i naš stih. Novi Sad. Matica srpska.

Mladenović, Aleksandar. 1968. Jezik Petra Hektorovića. Novi Sad, 1968.

Nenadović, Prota Matija. Rukopis Memoara Prote Matije Nenadovića. Arhiv Srbije, Pokloni i otkupi. 55/251.

Obradović, Dositej. 1961. Pismo Haralampiju. Sabrana dela. I. Ed. Đuro Gavela. Belgrade, Prosveta.

Ong, Walter J. 1982. Orality and Literary. The Technologizing of the Word. London. Methuen.

Popović, Miodrag. 1968. Istorija srpske književnosti: Romantizam. I. Belgrade. Nolit, 1972. Istorija srpske književnosti. Romantizam. II. Belgrade. Nolit.

Radević, Milorad. 1972. Izdanja „Memoara” Prote Matije Nenadovića. Zbornik istorijskog muzeja Srbije 8-9. Belgrade. 125-131.

Šević, Milan. 1925. Iz Brankova i iz Daničićeva kruga - pisma Đ. Daničića i njegovih drugova. Daničićev zbornik. Posebna izdanja SKA. Knjiga LV. Filosofski i filološki spisi. Knjiga 15. Belgrade - Ljubljana.

Smith, P. M., G. R. Tucker and D. M. Taylor. 1977. Language, ethnic identity and intergroup relations. One immigrant group's relations to language planning in Quebec. Language, ethnicity and intergroup relations. Ed. Howard Giles. London. Academic Press. 283-306.

Stojanović, Ljubomir. 1924. Život i rad Vuka Stef. Karadžića. Belgrade.

Stolz, Benjamin A. 1973. On the history of the Serbo-Croatian diplomatic language and its role in the formation of the contemporary standard. American contributions to the Seventh International Congress of Slavists (Warsaw, August 21-27, 1973), Vol. I, Linguistics and Poetics. The Hague, Mouton.

Trubeckoj, Nikolaj S. 1927. Общеславянский элемент в русской културе. К пробелеме русского самопознания. Собрание статей. Евразийское книгоиздательство.

Vince, Zlatko. 1978. Putovima hrvatskoga književnog jezika. Zagreb. Sveučilišna naklada Liber. 
Vinogradov, S. A., E. P. Naumov, and G. P. Čekanova. 1965. Из преписки Вука Караджича с русскими учеными. Славянское источниковедение. Москва. Наука. 187-200.

* Рад је претходно објављен у зборнику Научни састанак слависта у Вукове дане, 17/1, 99-112. 